\title{
Preface
}

\section{LESSONS FROM LIFE}

The son of a garment-industry cutter, I grew up with the knowledge that we were union people. Although I knew little about the complexities of labor relations and collective bargaining, I knew that the International Ladies' Garment Workers' Union (ILGWU) had provided what little schooling my immigrant father ever got. It helped him earn decent wages, and the benefits that it provided included home visits by Dr. Lamstein for $\$ 2$.

It was not until I attended Harvard Law School and studied labor law with the noted scholar Archibald Cox that I began to understand how complex the issues of labor law and labor relations were. Cox, like most of the Harvard faculty, discouraged emotional commitment and emphasized rigorous legal analysis. He did not care whether a particular opinion helped or hurt unions. Instead, he would ask, Was it consistent with statutory language, policy, and history? Did it follow established precedent? Cox was rigorous, stately, nonpartisan, knowledgeable, the model of an impartial expert, labor arbitrator, and mediator trusted by both unions and management. I realized in his class 
that my earlier views had been one-sided and uninformed. By the time I graduated, my goal was to become like Cox, a labor expert above the fray.

I soon got my chance. After graduation from law school, I went to work for the National Labor Relations Board (NLRB). It was a great place to work. The attorneys with whom I worked were dedicated and able. Many went on to distinguished academic and government careers. I thought them as tough and impartial as sheriffs in Western movies. They were neutral labor-law experts, like Archibald Cox.

When I left the Board to enter law teaching, I was determined to carry on this tradition of neutral expertise. My first labor-law students at Indiana University wondered whether I was pro-union or pro-management. My first scholarly article was a complex exposition and criticism of the Midwest Piping doctrine, which required an employer to withhold recognition from either of two competing unions. I argued that the doctrine did not protect employees and that it unnecessarily hindered employers. My article was carefully reasoned and researched. It betrayed no partisan bias. It supported changes in a technical labor-law issue that nobody really cared about.

My first connection with the labor movement, and the realities of labor law, occurred in the fall of 1965 when I was asked to teach labor law to a group of steelworkers who had been selected for academic potential from among hundreds of applicants. The program that brought them to campus was an experiment jointly developed by the United Steelworkers, Indiana University, and the Ford Foundation. The fellows chosen studied a full range of academic subjects, including English literature, political science, speech, and history, in addition to labor law. Once on campus they had the time of their lives. They eagerly read the assigned material and held heated debates about its significance. After class hours they could be found arguing the merits of unions with the conservative business students with whom they shared dormitory space.

I realized after a few weeks that I was learning a lot about industrial regulations from their questions. The fellows teased each other constantly and after a while began to tease me, focusing mainly on the irrationality of the law, much of which made no sense to them. They were not a group easily cowed by credentials - not mine and not any of the other faculty who taught in the program. I admired their eagerness to learn and envied their evident sense of commitment to the union and to each other. Their solidarity and devotion to the union made me less satisfied with my above-the-fray style of teaching and scholarship.

At the end of the graduation ceremony that marked the program's end, they 
locked arms and sang "Solidarity Forever," several with tears in their eyes. The fellows returned to their mills and factories, inspired and eager to repay the union for its support. But many soon became disillusioned. They had expected recognition of their learning and the opportunity to play a prominent role in their local unions using the skills that they had acquired at the university. But instead of new respect, they were met with resentment. The union's professional staff worried that their role was being preempted and their status undercut by the willingness of the fellows to state contrary opinions. The fellows quickly came to be resented as "wise asses" and "know-it-alls." The resentment on both sides became strong enough that several of the fellows began exploring new career paths and the union's district leadership demanded the right to name the fellows for the next year's program. This was my first, but far from last, encounter with the harmful effects of internal union political battles on the goals and performance of organized labor.

When the program ended, I was asked to teach at a leadership training program for leading members of Steelworkers District 30's staff, including the district director. I accepted immediately. I was eager to demonstrate my pedagogic skill to this important union group. The class, however, was a fiasco. Unlike the fellows, the staff members did not appreciate Socratic questioning. They were uncomfortable when I asked them to suggest answers to difficult issues. Worst of all, they overwhelmingly deferred to positions taken by their superiors in the union's hierarchy. Speaking truth to power was not part of their agenda. The district director himself answered a few of my questions, but when I prompted him for his reasoning, he simply restated his conclusions. It was, I realized, as hierarchical as the army in which I had served as an enlisted man.

From time to time during the 1960 , I served as a labor arbitrator. Arbitrators are private judges hired by employers and unions to interpret their agreement when disputes arise. They decide whether management has just cause to discharge workers, whether seniority is being properly acknowledged in promotions, and whether employees are being laid off, given vacation time, or paid in accordance with the agreement. What I learned as an arbitrator is how profoundly collective-bargaining agreements change the nature of the employment relationship. Collective bargaining, when it works properly, gives unions status and workers dignity. In the late I960s I also became active in the American Association of University Professors (AAUP), which had a large and active chapter on campus. The AAUP, although it neither engaged in nor advocated collective bargaining for professors, was as close to a union as faculty at major universities came in those days. Our chapter was large, active, con- 
tentious, and quite effective in promoting its major causes-academic freedom and faculty governance. The concept of academic freedom had been developed and defended by the AAUP in the aftermath of World War I. A team of major scholars had given the term practical meaning through a complex process that involved censuring universities that violated the rights of faculty members to teach, study, and publish the truth as they saw it. University administrators were eager to avoid censure by the AAUP on issues of academic freedom, and they wanted the goodwill of the local chapter because it was highly respected by the faculty, had access to the press, and could initiate the process of investigation and censure.

In 1969, with Professor Stephen B. Goldberg of the University of Illinois, I undertook to write a treatise on the law of union organizing. Organizing campaigns were then, as they are now, an area of complex legal regulation. Goldberg and I quickly realized that we did not know enough to properly evaluate the rationality of existing law. In a moment of academic daring facilitated by ignorance, we decided to investigate the relationship between the law and the realities of union organizing campaigns. It took us four years and six test studies to develop our research design. We wanted to identify elections likely to involve hard-fought, possibly illegal election campaigns by employers and their lawyers and consultants. Much to our surprise, the NLRB, where we both had worked and which regularly stressed the desirability of academic inquiry into Board rules, opposed our study. The Board argued that employees would be intimidated by our presence and that they would assume that we were employer spies and either refuse to talk to us or not tell us the truth. The Board's concern with the effect of our presence was based on assumptions very similar to those that the Board used in regulating campaign conduct-namely, that employees were attuned to nuances of coercion and could in fact be easily coerced into voting against union representation.

To get the names of the employees eligible to vote in the elections we wished to study, we were forced to sue the NLRB under the newly enacted Freedom of Information Act. We were the first of many academics to use the Act in support of our research and were rewarded with a strong favorable opinion by Judge J. Skelly Wright. ${ }^{1}$

From the first test study, our experience talking to workers was far different from the Board's prediction in almost every way. The employees answered honestly and fully. They had things to say about their jobs, their employers, and the unions that sought to organize them. They were pleased that we were genuinely interested. Indeed, it is difficult to overstate their eagerness to help make the 
law fairer generally. Our data further undermined my belief in the Board's expertise. What we concluded is that NLRB rules about what employers may say do not reflect an understanding of employee voting behavior. This conclusion, which I still believe to be true, has been questioned by many subsequent scholars. I explain in chapter 17 why I believe that subsequent research purporting to undermine our results is untrustworthy.

Quite apart from the careful statistical analysis of NLRB rules, I came away with a sense of the decency and intelligence of the workers whom we talked with. I also concluded sadly that the union organizers whose campaigns we studied, although invariably decent people, were often incompetent. They relied too much on canned handouts and did not spend enough time talking to and listening to the workers they were attempting to organize.

In our book Union Representation Elections: Law and Reality, we recommended less regulation of employer speech and greater access to employees for union organizers. Our study made something of a stir, but it was sharply criticized by union lawyers and pro-union academics who insisted that employer rhetoric required far more regulation than we suggested.

I joined the Yale law faculty in 1977 . About a year after I arrived, I received a call from the police union, which was seeking a lawyer to help with its upcoming negotiations with the state. I agreed to meet with members of the union's bargaining committee at the bar of the Sheraton Hotel. When I arrived, I had no trouble picking out the members of the police union even though they were out of uniform-leather jackets, bright sports coats, and shirts opened at the throat. Their manner was boisterous. Despite the laughter and drinks, their posture suggested wariness rather than relaxation.

They told me about their union, which had only recently been organized when the troopers had become dissatisfied with the traditional role of the Policemen's Benevolent Association. They had negotiated a contract once before, but the troopers remained discontented. The department was rife with favoritism. Assignments were based on getting along rather than on ability. Police were punished unfairly on the basis of unproven allegations. Senior members of the force were denied legitimate opportunity. No career ladder existed, and training was inadequate. The police were subject to arbitrary discipline. The police auxiliaries they had to work with were a joke and a menace. Each accusation was illustrated with stories that brought forth knowing laughter and expressions of anger.

The officers of the union wanted me to draft proposals and actually conduct the negotiations on their behalf. The offer was tempting. It seemed a won- 
derful way to learn both about police and about the intricacies of collective bargaining, a subject that I had taught but something that I had never engaged in. Also, the group was surprisingly appealing with their camaraderie, toughness, and cynical humor.

I spent at least a day each week during the next few months meeting with the troopers and learning about their jobs, concerns, and attitudes. I got a sense of how the world looked from the vantage point of those compelled to deal with human beings at their worst and to confront violent death, tragedy, hostility, and deception on a regular basis. They saw themselves as guardians of a society that did not appreciate them and as workers for a government that underpaid, scorned, and regularly mistreated them.

The negotiations proceeded slowly. The hardest part for me was not the discussions across the table but the free-for-all battles that occurred during the union caucuses when it was time to make concessions. It was during the caucuses that I earned my money and really learned about the art of compromise. But despite the tension in the bargaining committee, the state made a series of important concessions so that after a month of negotiations the outline of a fine contract had been agreed to. The cops were pleased and attributed far more of the success to my tough negotiating style than I deserved. It was their anger and militancy that worried the state negotiator, not my eloquence.

After a month of meetings, negotiations stalled. The cops, without my involvement, decided on a job action-one that had no precedent. During the weekend before the July 4 holiday, they stopped issuing tickets to motorists. They didn't stop patrolling. They arrested drunk drivers, and they continued to stop speeders, whom they warned to slow down. But the delighted motorists were let go with a verbal warning. It was a responsible job action, and the newspapers mostly pointed this out in their editorials. Theoretically, the cops who weren't issuing tickets were subject to discipline, but the sergeants and lieutenants never issued a single reprimand. After two days I got a frantic call from the state's lawyer, who desperately wanted an agreement before the July 4 weekend. We met the following Monday and quickly came to an agreement.

I learned a lot during that negotiation: most significantly, that the strike or strike threat is a powerful weapon; second, that imaginative job actions can sometimes be as effective as strikes; and third, that a union can gain more power when it has low-level supervisors on its side.

While at Yale, I was invited to spend a week at the Polish Academy for State and Law. I accepted eagerly because I knew that the country was being profoundly changed by the Solidarity labor movement. While in Poland, I met 
with many of the movement's leaders. I was particularly struck by the former factory worker Zbigniew Bujak and his close relationship with the dissident intellectual Jan Letinski. I realized that the alliance between workers and intellectuals mediated by the Catholic Church was what gave Solidarity its admirable vision.

When I returned to Yale, I saw that the worker-intellectual alliance that I so admired in Poland existed in Local 34 of the Hotel Employees \& Restaurant Employees International Union (HERE), which was seeking to organize Yale clerical and technical workers. The alliance was marvelous, illustrated in the relationship between the ninth-grade dropout Vincent Sirabella and his disciple, John Wilhelm, an honors graduate of Yale. I conducted a series of interviews with them and published an article about what I thought of as their insideoutside approach to organizing and collective bargaining. The organizing drive was dramatic and very well led. It was followed by an equally dramatic strike that ended in a surprising union victory. I spoke out on behalf of the union and conducted a series of interviews with its leaders. I became convinced that they were onto something valuable for the labor movement generally.

When I left Yale and joined the faculty at The University of Texas, I continued to study the organizing efforts of HERE, then directed by Sirabella.

The book on union organizing that I was planning to write was placed on hold in the I990s as I turned my scholarly attention to the issue of strike replacement. It all began innocently enough when a former student, James Brudney, then staff counsel to the Senate labor committee, asked me to testify on proposed legislation that made it unlawful for an employer to hire permanent strike replacements. During the hearing I began talking with a group of permanently replaced paperworkers from Maine. Their story moved me, and I decided to find out more about the strike. This led to a ten-year study of the strike of Local I4 of the United Paperworkers International Union (UPIU), which represented workers at International Paper's Androscoggin mill in Jay, Maine. During the course of the sixteen-month strike, Local i4 used a version of the inside-outside strategies previously employed by HERE. The local had superb leadership, widespread grassroots involvement, and highly creative strategies. It also had inspiring solidarity: fewer than 70 of the 1,200 strikers crossed the picket line. Local I4 also won over the media and enlisted the support of national political figures. Despite Local I4's heroic struggle, the strike was unconditionally called off in October 1988 . The local has since been decertified and the community destroyed.

Two things about the union's loss were particularly disheartening. First, the 
international union's leadership mishandled the strike. Many were hostile to the local's leadership and their outside advisors. Some seemed worried that the local leaders, who were heroes to the union's rank and file, would try to take over the unions.

The other disheartening aspect of the strike was the unfairness of the $\mathrm{Na}$ tional Labor Relations Act, which was, according to its preamble, designed to "enhance collective bargaining." Collective bargaining can work effectively only if there is a robust right to strike.

Since the mid-I980s, the union movement has been in a precarious situation. It has been confronted by increasingly hostile employers. Union jobs have moved overseas. Under the malevolently anti-union Bush Labor Board and the conservative courts, the law has grown dramatically more hostile. Unions have been sued under the Racketeer Influenced and Corrupt Organizations Act (RICO) and state tort law. They have been burdened with new reporting requirements, and their political efforts have been restricted. Inevitably, the oncepowerful union pay advantage has shrunk. Major organizing efforts by oncepowerful unions like the United Auto Workers and the United Mine Workers have failed.

But HERE, the union that organized Yale workers during the late I980s and through the I990s, developed a new and powerful approach to organizing and bargaining that depended on mobilizing the passion of its rank-and-file membership. Other unions seemed to be experimenting with new approaches as well. It was with the hope that organized labor was becoming more effective and that the mood of the country might be right for union growth that I undertook to write this book. 